\title{
Erratum to: Analysis of landslide causes and associated damages in the Kashmir Himalayas of Pakistan
}

\author{
Atta-Ur-Rahman • Amir Nawaz Khan • Andrew E. Collins
}

Published online: 8 July 2014

(C) Springer Science+Business Media Dordrecht 2014

\section{Erratum to: Nat Hazards (2014) 71:803-821 \\ DOI 10.1007/s11069-013-0918-1}

In the article, the name of one of the authors is not correct. The name Atta-ur Rahman should read Atta-Ur-Rahman.

The online version of the original article can be found under doi:10.1007/s11069-013-0918-1.

Atta-Ur-Rahman ( $($ )

Institute of Geography, Urban and Regional Planning, University of Peshawar, Peshawar, Pakistan e-mail: atta_urp@yahoo.com

\section{A. N. Khan}

Centre for Disaster Preparedness and Management, University of Peshawar, Peshawar, Pakistan

A. E. Collins

Disaster and Development Centre, Department of Geography, Northumbria University, Newcastle upon Tyne, UK 